\title{
PROGRAM KEMITRAAN MASYARAKAT (PKM) BERBASIS PENINGKATAN PRODUKTIVITAS PETANI-PETERNAK DALAM KONDISI WABAH COVID 19
}

\author{
Asrul", Aholiab Aoetpah*, Helda* \\ * Prodi Teknologi Pakan Ternak, Jurusan Peternakan Politeknik Pertanian Negeri Kupang \\ e-mail: asrulpoltani@gmail.com
}

\begin{abstract}
ABSTRAK
Kondisi lesunya perekonomian akibat COVID-19 bukan hanya dirasakan oleh masyarakat perkotaan, akan tetapi juga dirasakan oleh masyarakat pedesaan. Salah satunya yaitu masyarakat di Desa Raknamo Kabupaten Kupang. Keterbatasan pemenuhan kebutuhan pokok, rendahnya literasi akan pemeliharan ternak, pembuatan pakan dan pemeliharaan kesehatan ternak merupakan masalah yang dihadapi oleh masyarakat di Desa Raknamo yang tergabung dalam Kelompok Tani Fajar Pagi. Pembagian sembako, penyuluhan manajemen ternak sapi, penyuluhan pembuatan pakan, dan demplot pembuatan jamu merupakan metode yang digunakan dalam pemecahan masalah yang dihadapi masyarakat di Desa Raknamo. Hasilnya masyarakat sudah mendapatkan sembako yang bisa memacu semangat mereka untuk kembali produktif, mengetahui cara manajemen pemeliharaan ternak sapi, mengetahui cara pembuatan pakan, dan memahami pembuatan jamu untuk ternak.
\end{abstract}

Kata kunci : Covid 19, Raknamo, Fajar-Pagi, Ternak, Jamu, Penyuluhan

\section{PENDAHULUAN}

Sepanjang tahun 2020, virus COVID-19 telah mewabah ke seluruh dunia, termasuk Indonesia. Awalnya ketakutan terbesar dari ancaman COVID-19 hanya tertuju pada kesehatan manusia semata, namun efek ekonomi yang ditimbulkan ternyata lebih memprihatinkan. Perlakuan pembatasan sosial berskala besar (PSBB) sebagai kebijakan yang harus diambil pemerintah dalam mengurangi resiko penularan COVID-19, ternyata berdampak pada tersendatnya distribusi 
barang khususya kebutuhan pokok ke beberapa daerah. Distribusi barang pokok yang tersendat akan memicu lonjakan harga dan ujung ujungnya kondisi perekonomian akan merosot.

Kondisi merosotnya perekonomian akibat COVID-19 bukan hanya dirasakan oleh masyarakat kota perkantoran, akan tetapi juga dirasakan oleh masyarakat pedesaan yang umumnya berprofesi sebagai petani-peternak. Masyarakat petani-peternak yang ada di Desa Raknamo kabupaten Kupang merupakan salah satu kelompok masyarakat yang terkena dampak akibat COVID-19, baik dari sisi kesehatan maupun ekonomi. Banyak masyarakat di Desa Rakanamo yang takut ke pasar untuk bertransaksi. Akibatnya perputaran uang tidak terjadi di tengah-tengah masyarakat Desa Raknamo. Kurangnya perputaran uang, berimbas terhadap rendahnya pemenuhan kebutuhan pokok rumah tangga masyakarat Desa Raknamo.

Profesi sebagai petani-peternak oleh Masyarakat di Desa Raknamo sudah dilakukan secara turun temurun. Tanaman pertanian yang umumnya mereka budidayakan yaitu jagung sedangkan ternak yaitu sapi. Disaat COVID-19 menyerang, dan dengan kondisi perekonomian yang tidak stabil, banyak masyarakat di Desa Rakanamo yang mengalami gagal panen jagung. Akibatnya uang hasil panen jagung yang diharapkan sebagai sumber penghasilan utama untuk membeli kebutuhan pokok, hilang seiring kegagalan panen.

Masalah lainnya yaitu banyaknya warung makan yang tutup disaat COVID-19 mewabah yang menyebabkan permintaan akan daging sapi berkurang. Hal ini berimbas pada kurang terjualnya hasil ternak peliharaan masyarakat Raknamo, khususnya sapi. Hewan ternak yang sudah memasuki usia jual namun tidak laku menjadi masalah tersendiri bagi peternak. Durasi pemeliharaan sapi akan lebih lama, dan ini tentunya berimbas pada biaya pemenuhan pakan dan perawatan keseahatan ternak. Oleh karena itu perlu ada semacam stimulus bagi masyarakat khusus di Desa Raknamo agar bisa kembali beraktivtitas menjalankan roda perekonomianya dalam mengelola lahan pertanian dan peternakan mereka lagi.

Beberapa stimulus untuk menggerakkan kembali perkonomian masyarakat di Desa Raknamo dan belum pernah dilakukan sebelumnya yaitu: 
1) Memberikan bantuan pemenuhan kebutuhan pokok

2) Memberikan penyuluhan tentang cara memanjemen ternak agar biaya pemeliharaannya tidak terlalu tinggi termasuk pada persoalan pemenuhan pakan dan menjaga kesehatan ternak.

\section{MASALAH}

Berdasarkan latar belakang yang diuraikan maka Tim Program Kemitraan Masyarakat (PKM) Prodi Teknologi Pakan Ternak (TPT) Jurusan Peternakan Politeknik Pertanian Negeri Kupang bekerja sama dengan salah satu kelompok tani yang berada di Desa Raknamo (mitra) yaitu Fajar Pagi, menyepakati perlu adanya kegiatan pengabdian kepada masyarakat di Desa Raknamo agar setidaknya bisa memecahkan masalah pokok yang dihadapai petani-peternak di Desa Raknamo yaitu:

\section{Pemenuhan kebutuhan pokok}

Covid 19 dan merosotnya perekonomian ditambah kegagalan panen jagung tentunya sangat dirasakan berat oleh msayarakat Raknamo. Hal ini berimbas pada persoalan minimnya pemenuhan kebutuhan pokok mereka sehari-hari. Kebutuhan pokok yang tidak terpenuhi tentunya produktivitas untuk bertani dan beternak tidak bisa dimaksimalkan. Oleh karena itu perlu ada bantuan kebutuhan pokok bagi masyarakat Raknamo khususnya yang tergabung dalam Kelompok Tani Fajar pagi.

\section{Pemeliharaan Kesehatan dan Manajemen Pemeliharaan Ternak}

Ternak yang sedang dipelihara oleh anggota kelompok tani Fajar Pagi Desa Raknamo tentunya harus selalu dipastikan dalam keadaan sehat agar bobot tubuhnya terjaga sehingga harga jualnya tetap tinggi

\section{METODE PELAKSANAAN KEGIATAN}

Kegiatan Program Kemitraan Masyarakat (PKM) Berbasis Peningkatan Produktifitas PetaniPeternak dalam Kondisi Wabah COVID-19 berlangsung kurang lebih setahun selama tahun 2020 di Desa Raknamo, Kabupaten Kupang. Adapun metode pelaksanaan kegiatan dilakukan adalah : 


\section{Focus Group Discussion (FGD)}

FGD dilakukan antara tim pelaksana kegiatan program kemitraan masyarakat (PKM) bersama kelompok tani Fajar Pagi untuk memecahkan masalah yang dihadapi mayarakat di Desa Raknamo saat pandemi COVID-19.

\section{Pemberian Sembako}

Pemberian sembako ini dilakukan sebagai upaya untuk memenuhi kebutuhan pokok masyarakat Desa Raknamo khususnya yang tergabung dalam Kelompok Tani Fajar Pagi. Pemberian sembako diberikan secara langsung kepada masyarakat, namun tetap mematuhi protokol COVID-19.

\section{Penyuluhan Manajemen Pemeliharaan Ternak Sapi Penggemukan}

Penyuluhan ini dilakukan agar masyarakat bisa mendapatkan pengetahuan tentang cara praktis dan efesien dalam pemeliharaan ternak sapi penggemukan. Hal ini penting agar masyarakat tahu bagaimana cara memilih sapi bakalan untuk digemukkan, lama pemeliharaan, dan cara manejemen pakan.

\section{Penyuluhan Pembuatan Pakan Ternak}

Pakan disaat musim hujan, tidak menjadi masalah bagi peternak, karena rumput, lamtoro, gamal, dan jenis pakan edible (dapat dimakan) lainnya sangat melimpah. Menjadi masalah kemudian saat musim kemarau datang, biomassa pakan berkurang. Oleh karena itu perlu ada penyuluhan ke masyarakat bagaimana pengelolaan (pembuatan) pakan yang berlebih di musim hujan agar mampu bertahan dan digunakan saat musim kemarau datang. Selain itu pula masyarakat diberikan wawasan penting konsentrat dalam pemenuhan pakan ternak sapi.

\section{Demplot Pembuatan Jamu}

Menjaga kondisi hewan ternak agar kondisi tubuhnya selalu bugar tentunya hal yang harus dilakukan oleh peternak. Tidak adanya perawatan kesehatan ternak bisa menjadi celah ternak terserang penyakit. Biaya untuk berobat ternak di klinik kesehatan tentunya harus dikeluarkan dan menambah biaya operasionalnya lagi. Oleh karena itu perlu ada pelatihan / demplot pembuatan jamu untuk ternak yang berbahan dasar rimpang-rimpangan yang biasa tumbuh liar di pekarangan atau kebun. 


\section{Monitoring dan Evaluasi}

Monitoring dan evaluasi dilakukan untuk mengetahui sejauh mana program ini dapat mencapai target luaran yang diharapkan yaitu 1) adanya transfer ilmu ke masyarakat dari tidak tahu menjadi tahu dan memahami, 2) terpublikasinya kegiatan ini, baik di media cetak maupun elektronik, dan 3) adanya rencana kerja sama lanjutan dalam program kemitraan masyarakat ini.

\section{HASIL DAN PEMBAHASAN}

Desa Raknamo merupakan desa yang berada di administrasi kecamatan Amabi Oefeto Kabupaten Kupang. Penghasilan utama masyarakat Raknamo adalah bertani dan beternak. Jagung merupakan komoditas pertanian yang sering dibudidayakan oleh masyarakat di Kabupaten Kupang, khususnya di Desa Raknamo. Adapun dua komoditas utamanya yaitu sapi dan babi.

Kelompok Tani Fajar Pagi merupakan salah satu kelompok tani yang berada di Desa Raknamo. Kelompok Tani Fajar pagi berdiri sekitar tahun 2008 dengan jumlah anggota awal yaitu 15 orang kepala rumah tangga, dengan jumlah ternak (sapi) kurang lebih 15 ekor. Tahun 2020 jumlah anggota Kelompok Tani Fajar Pagi bertambah menjadi 50 orang. Bertambahnya jumlah anggota di Kelompok Tani Fajar Pagi disebabkan karena konsistennya kelompok ini dalam berproduktivitas baik di bidang pertanian maupun peternakan. Sebelum COVID-19 menyerang Kelompok Tani Fajar Pagi mampu memelihara 105 ekor sapi untuk digemukkan

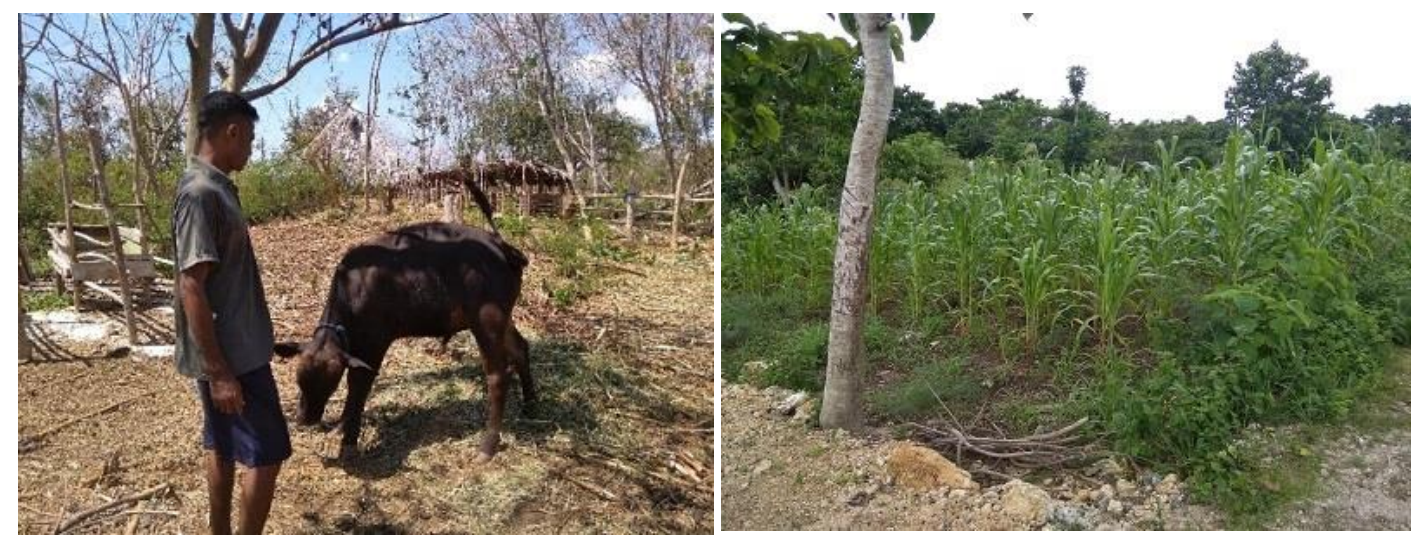

Gambar 1. Sapi dan Lahan Jagung di Desa Raknamo 


\section{1) Focus Group Discussion (FGD)}

Tahun 2020 merupakan tahun yang sulit dirasakan oleh petani peternak khususnya yang tergabung di kelompok tani Fajar Pagi Desa Raknamo. Hasil FGD dengan ketua kelompok tani Fajar Pagi menyampaikan 3 persoalan utama yang dihadapi selama COVID-19 mewabah yaitu 1) tanaman jagung yang masyarakat tanam rata-rata mengalami kegagalan panen akibat kemarau yang berkepanjangan, 2) Perdagangan sapi di pasar tradisonal mengalami penurunan, sehingga banyak sapi yang harus diperpanjang masa pemeliharaannya, 3) Jumlah pakan berkurang disaat musim kemarau, 4) Terkadang ada sapi sakit yang membutuhkan biaya pengobatan yang cukup menguras pendapatan peternak, 5) Administrasi peminjaman dana KUR (Kredit Usaha Rakyat) untuk membeli sapi bakalan penggemukan mulai tidak ramah administrasi
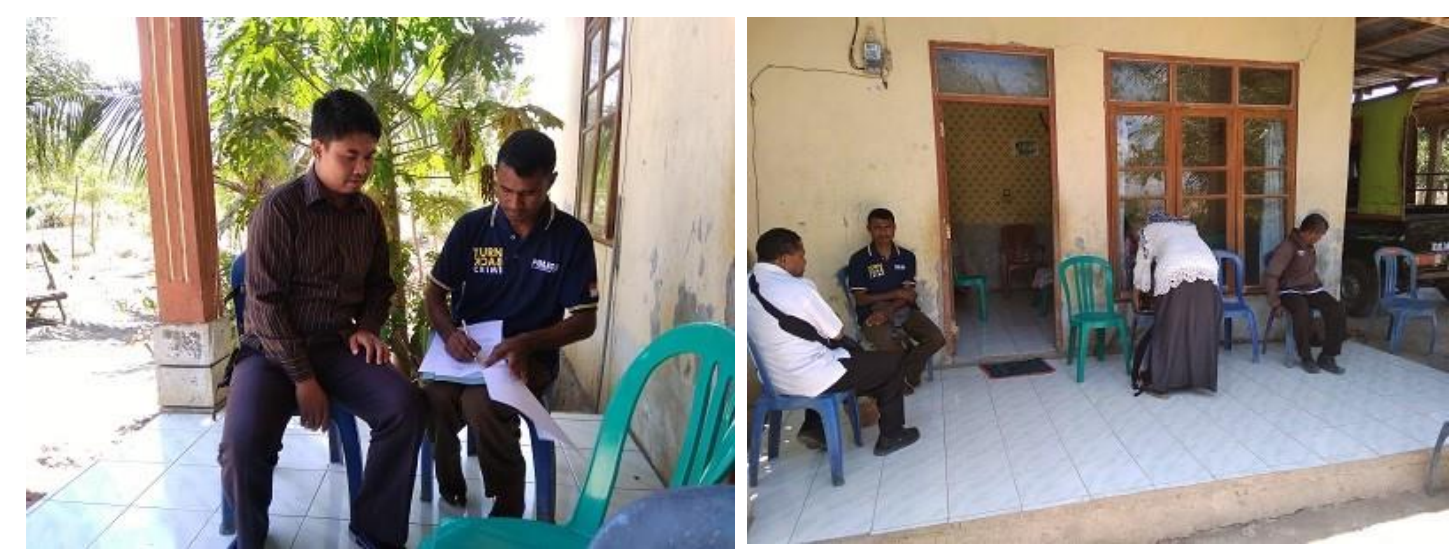

Gambar 2. Focus Group Discussion (FGD) dengan Kelompok Tani Fajar Pagi

Hasil FGD antara tim pogram kemitraan masyarakat dan pihak kelompok tani Fajar Pagi menyepakati untuk 1) membantu masyarakat dalam hal pemenuhan kebutuhan pokok sebagai akibat rendahnya daya beli masyarakat akibat kegagalan panen, 2) memberikan penyuluhan tentang manajemen pemiliharaan sapi potong, 3) penyuluhan tentang pembuatan pakan ternak, 4) Demplot pembuatan jamu untuk ternak. Semua kegiatan tersebut dilakukan di Desa Raknamo khususnya di Kelompok Tani Fajar Pagi secara offline namun tetap mematuhi protokol COVID19. 


\section{Pembagian Sembako}

Jumlah paket sembako yang dibagikan ke masyarakat berjumlah 50 paket, dimana isi paket sembako itu sendiri terdiri atas beras, gula, minyak goreng, teh, dan bihun. Penyerahan secara simbolis dilakukan oleh Wakil Direktur III Politeknik Pertanian Negeri Kupang kepada ketua Kelompok Tani Fajar Pagi. Masyarakat sangat berterima kasih atas bantuan sembako disaat kondisi mereka sangat membutuhkan bantuan khususnya sembako.
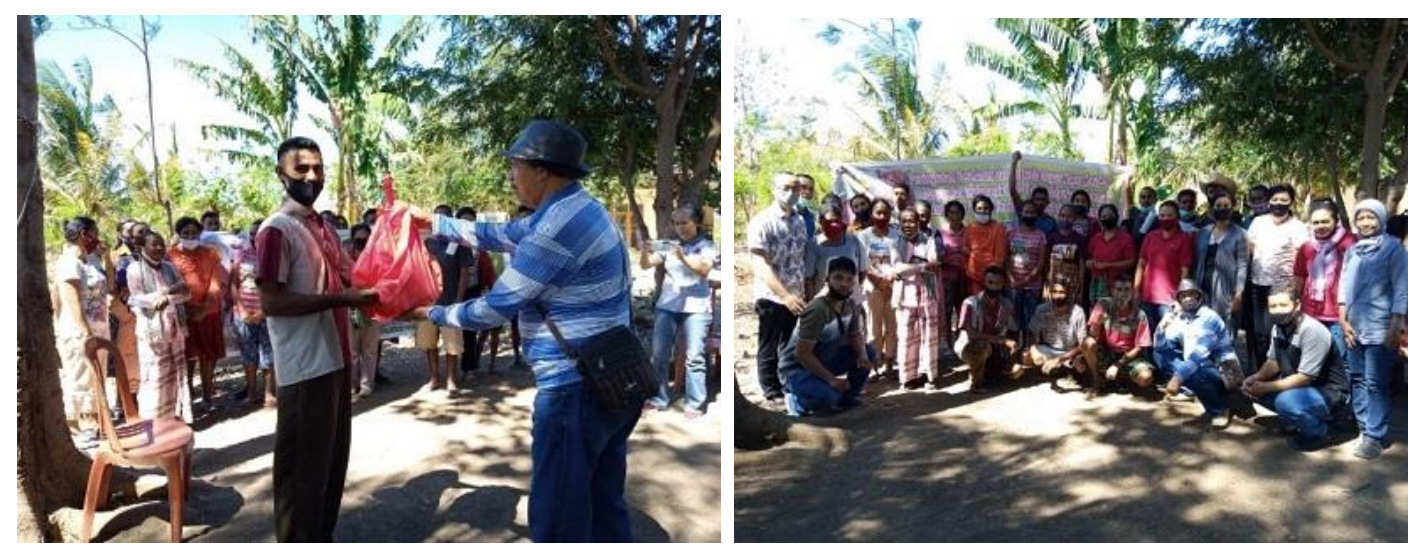

Gambar 3. Penyerahan sembako kepada masyarakat Raknamo

Tujuan utama dari pemberian sembako adalah untuk membantu mayasarakat kembali produktif dalam mengelola lahan pertanian dan peternakannya. Kemampuan berfikir dan melakukan kerja inovatif baru bisa terlaksana jika kebutuhan pokok bisa terpenuhi. Jadi sebagus apapun program pelatihan atau pembelajaran jika peserta sendiri belum bisa memenuhi kebutuhan akan badannya maka program tersebut akan sia-sia. Menurut detikfood, (2012) rasa lapar berakibat tidak fokusnya seseorang unutk bekerja termasuk belajar belajar.

\section{Penyuluhan Manajemen Pemeliharaan Sapi}

Kurang lebih 12 tahun para anggota kelompok tani Fajar Pagi sudah membudidayakan sapi potong sebagai salah satu sumber penghasilan mereka. Sapi potong yang digemukkan merupakan jenis sapi Bali. Jika kondisi sapi sehat dan pakan melimpah, mereka mampu mendapatkan keuntungan 2 juta perbulan dari 1 / ekor sapi yang telah terjual. Namun jika 
kondisi sapinya tidak bagus maka keuntungan yang didapatkan sangat kurang dari 2 juta per bulan.
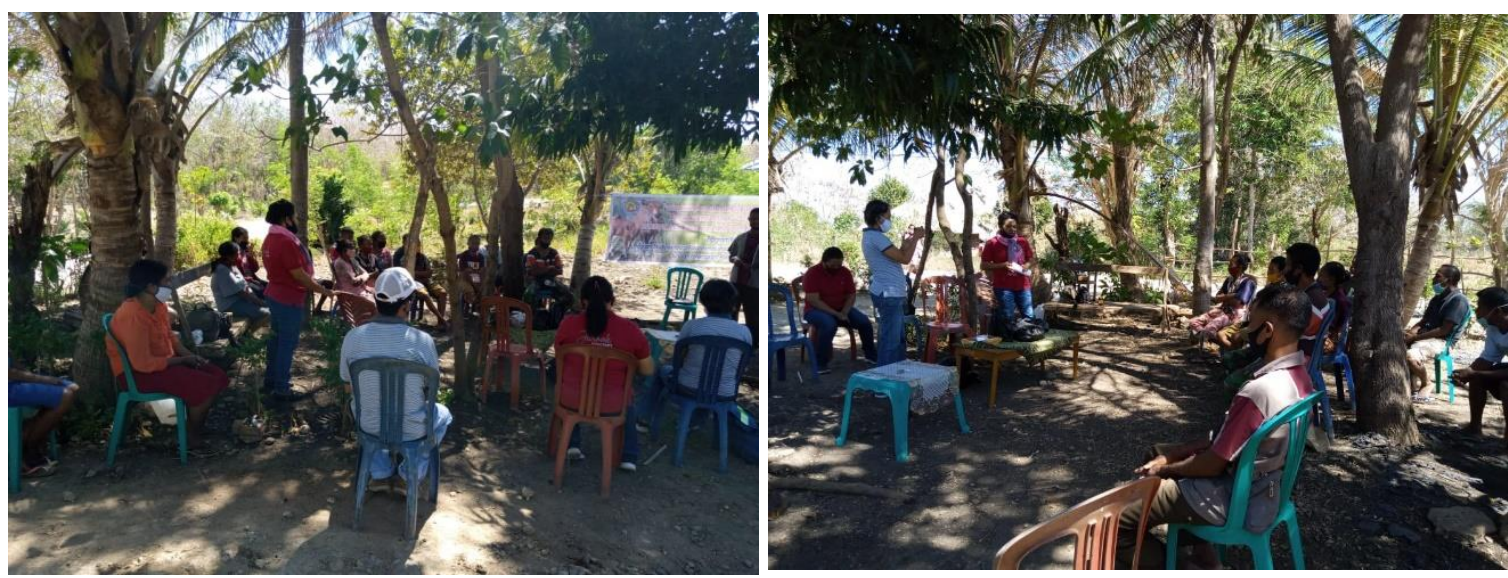

Gambar 4. Penyuluhan Manajemen Pemeliharaan Sapi Potong.

Materi penyuluhan pemeliharaan sapi potong sangat ditekankan kepada bagaimana memilih bakalan sapi yang tepat, agar berat badannya dapat bertambah dengan signifikan dalam 3-4 bulan penggemukan dan terpenting tidak mudah terkena penyakit. Setidaknya ada tiga aspek yang harus dipertimbangkan peternak jika memilih sapi bakalan yaitu 1) umur bakalan, 2) harga bakalan, dan 3) mutu bakalan. Lebih lanjut Muzani (2010) menyatakan ciri luar bakalan sapi (sapi Bali) yang bagus untuk dijadikan bakalan yaitu leher sapi pendek, badan segi empat panjang, tulang rangka besar, dan warna badannya normal tidak ada ada belang atau bintik putih badannya.

\section{Penyuluhan Pembuatan Pakan Ternak}

Masyarakat yang beternak tidak merasakan masalah dalam hal pemenuhan pakan jika musim hujan datang. Hal ini disebabkan karena hijauan melimpah mulai dari rumput liar, lamtoro dan gamal bisa ditemukan dimana saja. Pakan akan baru menjadi masalah jika musim kemarau datang, karena semua pakan menjadi terbatas jumlahnya. 

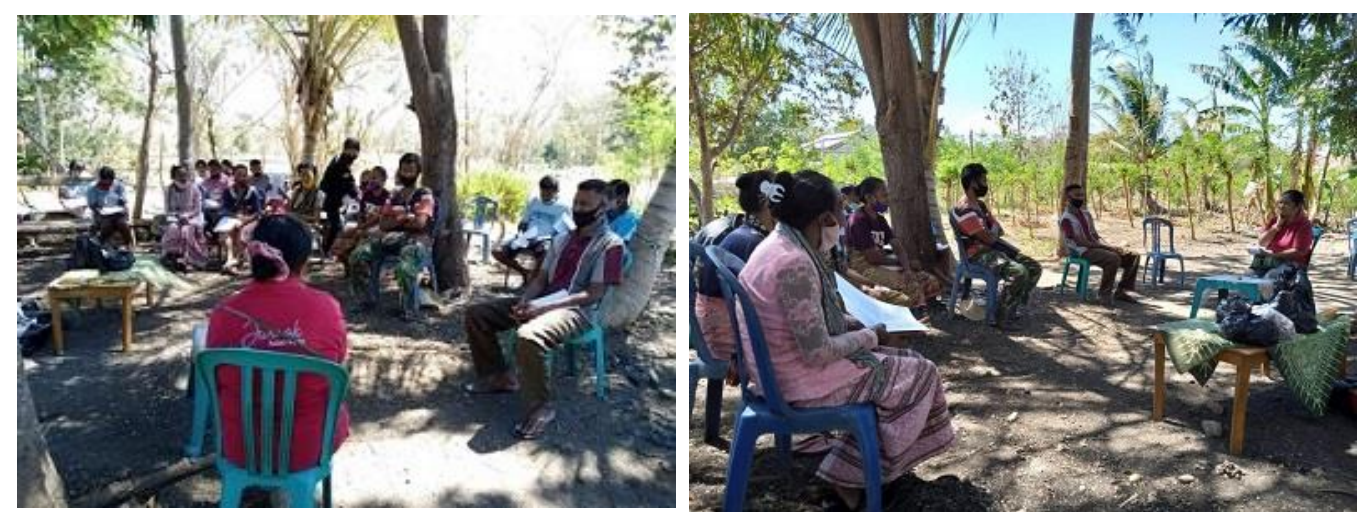

Gambar 5. Penyuluhan Pembuatan Pakan Ternak

Menurut Sampurna (2016) pakan yang diberikan ke ternak sapi dapat berupa pakan hijuan, pakan konsentrat penguat), dan pakan tambahan. Anggota Kelompok Tani Fajar Pagi sendiri sejauh ini cuma mengetahui namanya pakan hijauan yang langsung diambil dari alam dan langsung diberikan ke sapi. Selain itu pula masyarakat juga baru mengetahui bahwa pakan hijauan seperti rumput dan gamal dapat diawetkan menjadi silase, dan diberikan ke ternak jika sumber pakan hijaun segar sudah terbatas jumlahnya dimusim kemarau.

Penyuluhan pembuatan pakan ternak juga memberikan arahan ke masyarakat tentang pentingnya pemberian konsentrat ke ternak khusus sapi potong agar proses pertumbuhannya lebih cepat. Pertumbuhan dan pertambahan bobot yang cepat tentunya akan mengurangi durasi pemeliharaan dan mampu menghemat biaya operasional yang tidak terduaga, seperti sapi tiba-tiba sakit. Konsentrat sendiri dapat diartikan sebagai jenis pakan yang dimana kandungan protein atau energinya lebih tinggi daripada kandungan seratnya, contohnya bungkil kelapa, dedak, dan bungkil jagung (Kallo dan Tondok, 2019).

Bungkil jagung merupakan salah satu konsentrat yang bisa dimanfaatkan secara maksimal oleh masyarakat. Kabupaten Kupang terkhususnya masyarakat di Desa Ranamo termasuk daerah penghasil jagung terbesar di NTT. Bahkan Kabupaten Kupang menyiapkan lahan 2.600 ha untuk mengembangkan sektor perjagungan (Antara, 2020). Terpenting Kelompok Tani Fajar Pagi termasuk kelompok yang ikut serta dalam program pemerintah provinsi NTT 
yaitu tanam jagung panen sapi. Hal ini tentunya bisa berimpilkasi akan besarnya potensi bungkil jagung yang dihasilkan sebagai produk limbah pertanian.

\section{Demplot Pembuatan Jamu untuk Ternak}

Salah satu biaya tidak terduga yang terkadang bisa membuat peternak merugi adalah biaya pengobatan akibat ternak jatuh sakit. Terpenting bagi peternak adalah bagaimana menghindari agar ternak tidak jatuh sakit. Menjaga kondisi kebugaran ternak adalah suatu hal yang harus diperhatikan peternak. Pemberian pakan yang berkualitas, pembersihan kandang yang rutin, dan pemberian jamu merupakan langkah-langkah yang dilakukan agar kondisi kesehatan ternak tetap stabil.

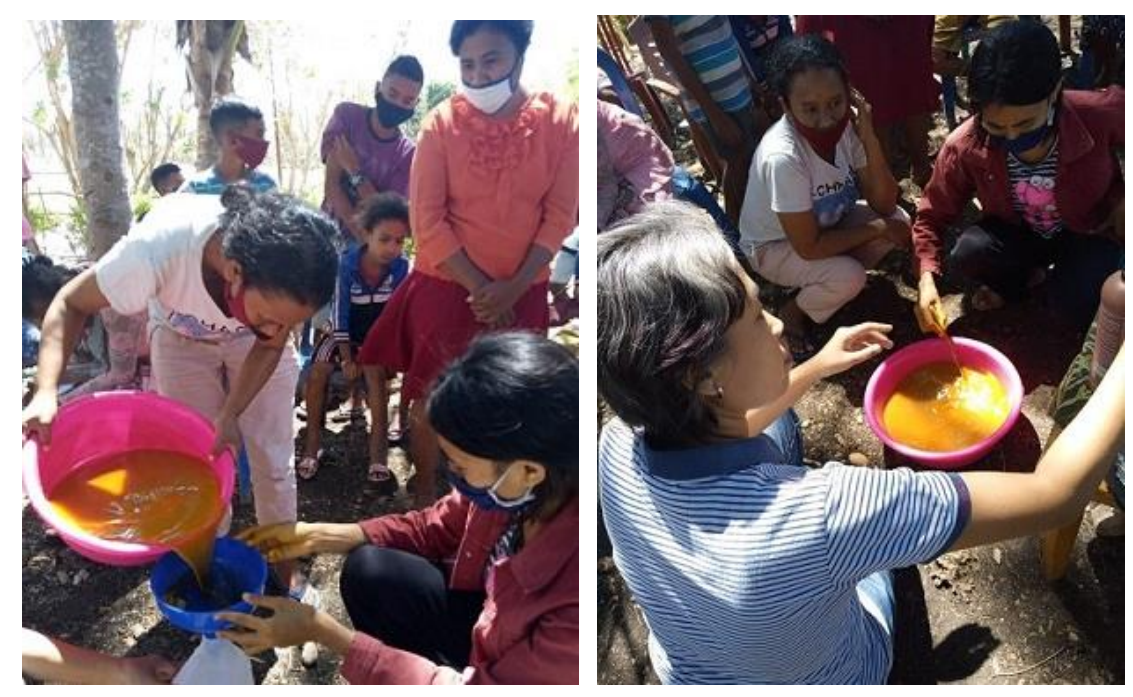

Gambar 6. Demplot Pembuatan Jamu Untuk Sapi

Jamu sendiri secara definisinya disebut sebagai obat, namun banyak juga yang mengatakan bahwa jamu adalah suplamen yang menjaga daya tahan tubuh. Sebagain besar masyarakat cuma mengetahui bahwa jamu itu hanya untuk manusia, namun untuk ternak tidak ada. Bahan pembuatan jamu untuk ternak umumnya dapat diperloleh dari tanaman rimpang-rimpangan yang tumbuh di sekitar rumah atau pekarangan. Kunyit, jahe, dan temulawak merupakan contoh tanaman rimpangan yang bisa digunakan sebagai bahan pembuatan jamu untuk ternak. 
Jamu untuk ternak sendiri di daerah luar NTT, khususnya di Jawa sudah menjadi komoditas ekonomi sendiri yang diperjual belikan di market place. Khusus di sapi pemberian jamu disesuaikan dengan kondisi nya. Sapi yang sakit dengan ciri kondisi nafsu makan yang menurun, biasanya diberikan $250 \mathrm{cc}$ jamu 2 kali sehari, namun yang sehat, cukup dosis yang sama dengan pemberian 3 kali dalam seminggu (Abdurahman dan Istiqomah, 2009).

\section{Monitoring dan Evaluasi}

Hasil monitoring dan evaluasi akan target luaran yang diharapkan bisa dikatakan tercapai semua. Masyarakat sudah memahami pembuatan jamu, mengetahui pemaksimalan hijauan di musim penghujan yang melimpah untuk dijadikan silase, dan mengetahui cara manajemen pemeliharaan sapi potong khususnya dalam pemilihan bakal sapi potong. Dokumentasi akan pelaksanaan program kemitraan pula sudah terpublikasi di Pos Kupang dan YouTube. Terakhir disepakati kegiatan selanjutnya jika program kemitraan terus berlanjut maka para peternak di Kelompok Tani Fajar Pagi meminta untuk diajari secara teknis pembuatan konsentrat dari bahan baku yang terdapat di Desa Raknamo.

\section{SIMPULAN DAN SARAN}

\section{SIMPULAN}

Program Kemitraan Masyarakat (PKM) berbasis peningkatan produktivitas petani-peternak dalam kondisi wabah COVID-19 di Desa Raknamo Kabupaten Kupang telah dilaksanakan melalui kegiatan pembagian sembako, penyuluhan pemliharaan ternak, penyuluhan pembuatan pakan, dan pembuatan demplot pembuatan jamu ternak.

\section{SARAN}

Perlu ada kegiatan program lanjutan kemitraan masyarakat ini, agar masyarakat bisa terampil dalam pembuatan silase dan pakan konsentrat 


\section{UCAPAN TERIMAKASIH}

Ucapan terima kasih kepada Pusat Penelitian dan Pengabdian Kepada Masyarakat (P3M)

Politeknik Pertanian Negeri Kupang, atas dukungan materiil dan non materill atas terlakasananya kegiatan pengabdian ini.

\section{DAFTAR PUSTAKA}

Abdurahman dan Istiqomah, N. 2009. Jamu Ternak Organik. Balai Pengkajian Teknologi Pertanian Jawa Timur. Diperoleh pada jatim.litbang.pertanian.go.id. pada tanggal 15 Oktober 2020.

Antara. 2020. Kabupeten Kupang siapkan 2.600 ha lahan pengembangan jagung. Diperoleh di https://kupang.antaranews.com/berita/39565/kabupaten-kupang-siapkan-2600-ha-lahanpengembangan-jagung pada tanggal 14 Oktober 2020

Detikfood. 2012. Rasa Lapar Kurangi Konsetrasi Belajar Anak. Diperoleh di https://food. detik.com/makanan-dan-gizi-anak/d-2017272/rasa-lapar-kurangi-konsentrasi-belajar-anak.

Diperoleh pada tanggal 15 Oktober 2020.

Kallo, R dan Tondok, A.R. 2019. Membuat Pakan Konsentrat Untuk Ternak Sapi Potong. Diperoleh di sulses.litbang.pertanian.go.id pada tanggal 15 Oktober 2020.

Muzani, Achmad. 2010. Memilih Bakalan Sapi Bali. Penerbit : Balai Pengkajian Teknologi Pertanian (BPTP) NTB Kementrian Pertanian. Mataram.

Sampurna, I, Putu. 2016. Pakan Sapi Bali. Fakultas Kedokteran Hewan Universitas Udayana., Bali. 
Jurnal Pengabdian Masyarakat Peternakan

Vol. 05 No. 2 Tahun 2020

e-ISSN: 2502-5392

onm 